\title{
Assessment of Heavy Metals Pollution in Dumpsites in Ilorin Metropolis * Abdus-Salam N.
}

\begin{abstract}
Speciation and distribution of heavy metals in soil controls the degree to which metals and their compounds are mobile, extractable, and plant available. Eight strategically located dumpsites in llorin metropolis (an averagely growing city and a state capital) were chosen for dumpsites-soil characteristics study. Both the estimated total and potentially available metals were studied using EPA 1311 and Tessier's et al methods respectively. It was observed that the groundwater is vulnerable to contamination as no treated basement to adsorb toxic metals was provided for in the sites. About $70 \%$ of $\mathrm{Mn}, \mathrm{Fe}, \mathrm{Zn}, \mathrm{Cd}$ and $\mathrm{Pb}$ were found in the exchangeable bound to carbonate and bound to iron/manganese oxide fractions. These fractions represent the mobile and lethal portion of the total metals to the ecosystem. The metal enrichment factor revealed that $\mathrm{Zn}, \mathrm{Cd}$ and $\mathrm{Pb}$ were of anthropogenic source while Fe is of natural and anthropogenic sources. The dumpsites in llorin, therefore pose negative consequences on the soil and groundwater environment.
\end{abstract}

\section{Introduction}

The gradual increasing population industrial processes particularly in major cities of the world has led to emergency of civilization that have greater impact on the environment. The industrial revolution gave birth to environmental pollution and the large volume of industrial chemical discharges has added to the growing load of untreated domestic waste. The disposal of domestic, commercial and industrial garbage in the world is a problem that continues to grow with human civilisation and no method so far is completely safe. Experience has shown that all forms of waste disposal have negative consequences on the environment, public health, and local economies.

Dumpsite is an old traditional method of waste disposal similar to landfill method of waste management. Dumpsites are often established in disused quarries, mining or excavated pits away from residential areas. Designated government agency, corporate bodies and some individuals collect wastes routinely into these dumpsites. Here in Nigeria and particularly in Ilorin, modern landfill facilities are not found in these dumpsites; consequently sorting-out of wastes into degradable, non-degradable and recyclable precious materials cannot be achieved. Poor management of dumpsites could create a number of adverse environmental impacts, including wind-blow litter, attraction of mice and pollutants such as leachate, which can pollute underground soil bed, and / or aquifer. Landfill gas mostly composed of methane and carbon dioxide are produced through biodegradation of such waste.
Leachate from dumpsites is of particular interest when it contains potentially toxic heavy metals. These metals are known to bioaccumulate in soil and have long persistence time through interaction with soil component and consequently enter food chain through plants or animals [Dosumu, 2003]. Household and industrial garbage may contain toxic materials such as lead, cadmium, mercury, manganese from batteries, insect sprays, nail, polish, cleaners, plastics polyethylene or PVC (polyvinyl chloride) made bottles and other assorted products.

Inorganic chemical contamination of the environment is due essentially to anthropogenic source, improper disposal and lack of awareness of the health-risk created by such indiscriminate disposal. Lead, cadmium manganese, arsenic and mercury are pollutants which have unknown physiological benefit when ingested [Abdus-Salam and Adekola, 2005a; Brady and Weil, 1999]. There is increase awareness of keeping a friendly hygienic environment and Kwara State government has established an out-fit: Kwara State waste management and control agency for proper collection and disposal of wastes generated through domestic, commercial and industrial activities in all cities in the state. This exercise has increased the number of dumpsites without eliminating the local ones.

The build up of heavy metals in soil from anthropogenic sources have been reported to be harmful to crops and human health (Smith et al, 1996). Sources of these metals ranges from industrially and municipally generated (Gibson and Farmer, 1983; Olajire and Ayodele, 1998), automobile emission (Olajire

* Department of Chemistry Department, University of Ilorin, Nigeria. nasalami2002@yahoo.co.uk 
et al, 2002), agricultural and land practices (Uba et al, 2008). Municipal solid wastes were reported to contain large amount of persistent organic pollutants (Minh et al, 2006). The concentrations and transformations of heavy metals in solid municipal wastes lead to accumulation in the food web (Gimmler et al, 2002). The views of many researchers is that the current trend in the municipal wastes disposal and management practices may increase the heavy metal burden of the soil and underground water (Albores et al, 2000, Okoronko, 2006, Elaigwu et al, 2007). Most of these metals have no known physiological relevance to the survival of plants and animals

The characteristics of the dumpsites in Ilorin are of environmental interest for (1) most active dumpsites are now located within the city due to population influx and expansion (2) improper treatment of the dumpsites for necessary basement that can adsorb toxic leachate and (3) lack of pre-classification and sorting-out of wastes disposal. This research work was undertaken to ascertain the level of soil pollution of major dumpsites in Ilorin metropolis in order to characterise the nature of waste being generated. Some physicochemical parameters were also investigated so as to determine the relative mobility of toxic metals in the soil and make appropriate recommendations to Federal Environmental Protection Agency (FEPA) and Kwara State Environmental Protection Agency (KWEPA) on the state of soil pollution of the dumpsites in Ilorin.

\section{Materials and Method}

\section{Sampling and Sample Preparation}

The sampling areas covered historic and modern dumpsites within and around Ilorin metropolis. The year of existence of the dumpsites varied markedly. A total of eight sites were chosen. Table 1 give dumpsites description, year of existence and locations. Because soils are intrinsically varied, random samplings in five spots per dumpsites were taken. The samples were collected into polyethylene bags, at depth of about $15-20 \mathrm{~cm}$ below the earth surface and thoroughly mixed to form a composite. The samples were taken to the laboratory; air-dried and sieved into three fractions, $\theta \leq 0.25 \leq 0.50 \mathrm{~mm}$ in diameter. $\theta \leq 0.25 \mathrm{~mm}$ samples from all sites were used for further analysis.

Reagents: All chemical used were pure analar or BDH grade. Where reagents were prepared de-ionised water was used. All glassware was thoroughly washed.

\section{Analytical Methods}

The organic carbon contents of all samples were separately determined by the dichromate oxidation of Walkly and black method as obtained in literature [IITA, 1979; Abdus-Salam and Adekola, 2005b]. The $\mathrm{pH}$ of the soil samples were measured in water by glass electrode method involving 1:1 soilwater mixture using a MicropH 2000 model of a Hanna pH-meter [IITA,1979]. The moisture contents of the air-dried $\phi \leq 0.25$ samples were determined [Kunze and Dixon, 1986]. Each experiment was carried out on triplicate samples from each location. The results were recorded as mean value of the triplicate.

\section{Extraction Procedure}

Two essential extraction procedures were employed. The toxicity characteristic leaching procedure EPA Method 1311 that utilises dil. / conc. $\mathrm{HNO}_{3}$ and the common sequential modified tessier method [http: 2006; Tessier et al, 1979] was separately used. The EPA 1311 gave a single composite extract, while Tessier method gave rise to five fractions. The product of extractions (filtrates) were separately analysed for trace elements using an Alpha 4 Chem. Tech. Analytical Atomic Absorption Spectrometer (AAS) with graphite atomiser. Extractions were carried out in triplicates for each location. The triplicate AAS values were averaged and the amounts of trace metals were recorded as mean value.

\section{Results and Discussions}

The description of dumpsite locations and year of existence is presented in Table 1 and pictorial in Fig. 1. They are within two (2) to twenty-one (21) years old. The more recently created dumpsites are more actively used as some old ones now fell within or close to residential areas.

The mean $\mathrm{pH}$ values in 1:1 soil: water suspension ranges from 5.4 for Atoto Warehouse to 7.7 for Ita-Amoh as shown in Table 1. The more active sites exhibit neutral to slightly basic $\mathrm{pH}$ while old or inactive sites exhibit, slightly acidic $\mathrm{pH}$. All samples were sufficiently air dried before use. The weight of soil sample used for extraction may be taken as absolute value, since percentage moisture content makes practically no difference. The organic matter is relatively low ranging between 1.64 and 4.20. The tendency for exchangeable cations to bind to the organic 
phase will be low due to low organic content value. The $\%$ organic matter obtained here was within the ranges observed for some tropical soil type: oxisol (4.05), Ullisol (1.86) and Molisol (1.16) [Chip-Appel and Lena 2002]. The comparative results of dilute and conc. $\mathrm{HNO}_{3}$ extraction is presented in table 3 . In all cases, extraction with concentrated $\mathrm{HNO}_{3}$ gave slightly higher metal values.

The efficiency of extraction is thus better under the same conditions with conc $\mathrm{HNO}_{3}$. The general variations trend in the amount of metals across the dumpsites justified the diversity and complexity of the waste been generated in Ilorin. Fig 2A-E is bar charts describing comparative extractions of metals using dilute and conc $\mathrm{HNO}_{3}$ as extractant. It is evident from Table 3 and Fig. 2A-E that conc $\mathrm{HNO}_{3}$ was a better extractant. The differences in the extents of extraction suggest among other things that (1) both dilute and conc
$\mathrm{HNO}_{3}$ may not have extracted all the pollutants and (2) the actual toxicity of the metals based on the total estimated values may create erroneous impression, as toxicity is largely determined by form, availability and speciation and not by concentration or amount of metals in solution.

The normalisation of these pollutants was statistically carried to determine to differentiate the enrichment sources of these metals and reported in Table 4. The enrichment factor was calculated using $\mathrm{Mn}$ as the metal from natural source [Loring, 1991]. The metal: $\mathrm{Mn}$ ratio varied across all the metals. The ratio is consistently higher for $\mathrm{Fe}$, consistently lower for $\mathrm{Cd}$ and $\mathrm{Pb}$ while $\mathrm{Zn}$ gave varied values. All values less than 1 is suggestive of anthropogenic source of the metal Loring, 1991], while values higher than 1 is an indication of multiple sources: anthropogenic and natural sources.

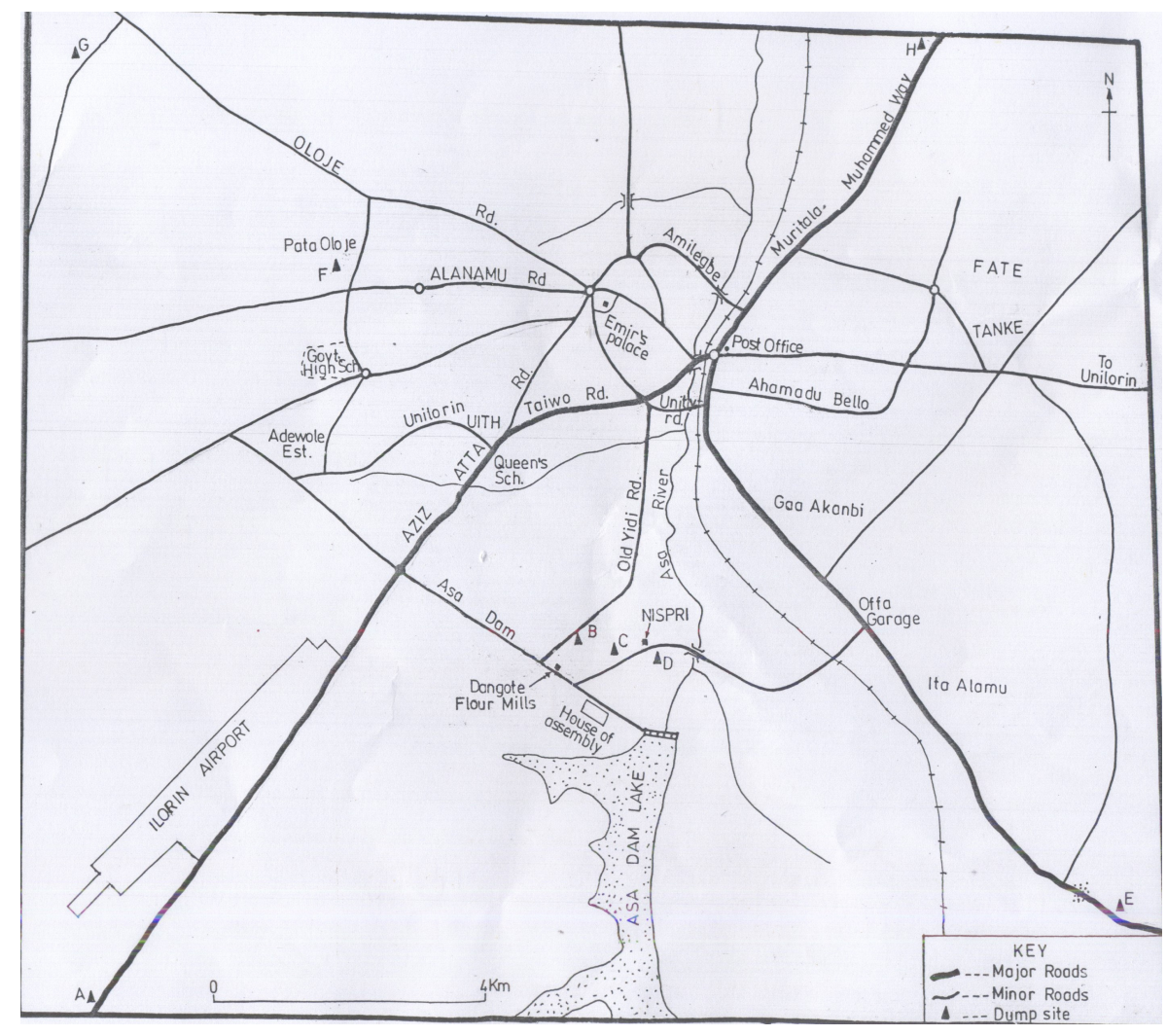

Fig1: Map of Ilorin showing the sampling points 
The mean concentrations (Metal-mg/kg-soil) of trace metals in step-wise extraction from all sites are shown in table 5: The speciation and distribution of heavy metals in soils controls the degree to which the metals and their compounds are mobile, extractable, and plant available. The concentration of the mobile species in soil is an index of pollution of an environment as this concentration could be easily leached into groundwater.

Metals associated with fractions 1,2 and 3 (exchangeable, bound to carbonates and bound to iron/manganese oxides) are influenced by soil $\mathrm{pH}$ and changes in redox potentials. The environmental impact of these metals is governed by the sum concentrations in these three fractions. The neutral $\mathrm{pH}$ will make the retention time on bound to iron/manganese fraction longer [Naidu et al 1998; Backstrom et al, 2003]. From Table 5, fractions 1 and 2 account for about $70 \% \mathrm{Cd}$ and $\mathrm{Pb}$. These metals are considered mobile under common thermodynamic soil conditions and could easily pollute the groundwater. Mn, $\mathrm{Zn}, \mathrm{Cd}$, and $\mathrm{Pb}$ concentrations are practically low or below detection level in the residual fraction. Therefore, the bulk of the metals are in a form that is lethal in the environment. Change in $\mathrm{pH}$ to a lower value and a high microbial biodegradation activity will release substantial metals in fractions 3 and 4 (bound to iron/manganese and organic matter) into soil solution.

\section{References}

Abdus-Salam, N. and Adekola, F. A. (2005). Physico- chemical characterization of some Nigeriangoethite mineral samples. Ife J. Sci. 7(1), 131 - 137.

Abdus-Salam, N. and Adekola, F. A. (2005). The influence of $\mathrm{pH}$ and adsorbent concentration on adsorption of lead and zinc on a natural goethite. African J. Sci. Tech. (AJST). 6 (2), 55-66. Albores, A.F., Perez-Cid, B., Gomes, E.F. and Lopez, E.F. (2000). Comparison between sequential extraction procedures and single extraction procedures for metal partitioning in sewage sludge samples. Analyst, 125, 1353-1357

Backstrom, M., Dario, M., Karlson, S., Allard, B. (2003). Effect of fulfic acid on mercury and cadmium on goethite. Sci. Total Environ., 304, 257-268
The high concentration of Fe could be partly due to the Fe content of Ilorin soil and partly due to high content of Fe-based waste materials been generated through domestic and industrial wastes. Most of the $\mathrm{Fe}$ is bound to organic matter and residual.

\section{Conclusion}

The contents of garbage been generated from different parts of Ilorin is essentially the same as reflected by the close range of values for the trace metals studied. The enrichment factor showed that $\mathrm{Zn}, \mathrm{Cd}$ and $\mathrm{Pb}$ are essentially from anthropogenic source while $\mathrm{Fe}$ originates from natural and anthropogenic sources. There is a growing concern on the gradual build-up of toxic metals in the dumpsites as greater percentage is in the mobile fractions. These will become available to plants or groundwater over geological time scale where they are biomagnified. The information on the potentially available trace metals as opposed estimated total metals $\left(\mathrm{HNO}_{3}\right.$ - extraction) may be useful in designing remediation programme for contaminated sites. It provides information on the relationship between contaminants and the environment. It is recommended that the government should consider a basement treatment for dumpsites before use. This will provide sorption surfaces for pollutant and prevent groundwater contamination.

Brady, N. and Weil, R. (1999).The nature and properties of soil. Prentice Hall, Upper saddle River, New Jersey, pp 74-92.

Chip-Appel and Lena ma (2002).

Concentration, $\mathrm{pH}$, and surface charge

effects on cadmium and lead sorption in three tropical soils. J. Environ. Qual., 31, $581-589$.

Dosumu, O. O., Salami, N. and Adekola, F. A. (2003). Comparative study of trace element levels. Bull. Chem. Soc. Ethiop17 (1), $107-112$.

Elaigwu, S.E, Ajibola, V.O. and Folaranmi, F.M. (2007). Studies on the impact of municipal waste dumps on sourounding soil and quality of two cities in Northern Nigeria. J. Applied Sci., 7 (3), 421-425 
Gimmler, H., Carandang, J. Boots, A., Reisberg, E. and Woitke, M. (2002). Heavy metal content and distribution within a woody plant during and after seven years continuous growth on municipal solid waste MSW bottom slag rich in heavy metals. J. Appl. Bot., 76, 203-217

http://www.epa.gov/epaoswer/haswaste/tet April, 2006 /pdfs/1311.pdf. Retrieved on28th

IITA (International Institute of Tropical Agriculture) (1979). Selected Methods for Soils and Plants Analysis. Manual Series No 1, 3 - 29 .

Kunze, G. W. and Dixon, J. B. (1986). Pretreatmement for mineralogical analysis. In. Methods of soil analysis.A. Klute (ed)

Part 1. Physical and mineralogical methods. $2^{\text {nd }}$ Edn., Madison, W. I. Soil Sci. Soc. Am., 91 - 100KWMC (Kwara state waste management and control, offa road, Ilorin, Nigeria.

Loring, D. H. (1991). Normalization of heavy metal data from estuarine and costal sediments. ICES J. Mar. Sci., 48, 110 115.

Mathe-Gasper, G., Mathe, P., Szabo, L., Orgavanyi, B., Uzinger, N. and Anthon, A. (2005). After effect of heavy metal pollution in a brown forest soil. Acta Biologica Szegedients, 49 (1-2), 71-72 Minh, N.H., Minh, T.B., Kajiwara, N., Kunisue, T., Subramanian, A., Iwata, H., Tana, T.S., Baburajendran, R., Karuppiah,
S., Viet, P.H., Tuyen, B.C. and Tanabe, S. (2006). Contamination by persistent organic pollutants in dumping sites of Asian developing countries: Implication of emerging pollution sources. Environ.

Contam. Toxicol., 50, (4), 474-481

Naidu, R., Sumner, M. E. and Harter, R. D. (1998). Sorption of heavy metal in strongly weather soils. An overview. J. Environ.

Geochem. Health, 20, 5-9.

Okoronkwo, N.E., Odemelam, S.A. and

Ano, O.A. (2006). Level of toxic elements in soils of abandoned waste dumpsites. Afr, J. Biotechnol., 5 (13), 1241-1244 Olajire, A.A. and Ayodele, E.T. (1998). Heavy metals analysis of solid municipal waste in the western part of Nigeria. Water, Air and Soil Pollut., 103, 219-228 Olajire, A.A, Ayodele, E.T. Oyediran, G.O. and Oluyemi, E.O. (2003). Levels and speciation of heavy metals in soils of industrial southern Nigeria. Environ.

Monit. Assess. 85, 135-155

Smith, C.J., Hopmans, P. and Cook, F.J. (1996). Accumulation of $\mathrm{Cr}, \mathrm{Pb}, \mathrm{Cu}, \mathrm{Ni}$, $\mathrm{Zn}$ and $\mathrm{Cd}$ in soil following irrigation with untreated effluents in Australia. Environ. Pollut., 94, 317-323

Tessier, A., Campbell, P. G. C. and Bisson, M. (1979). Sequential extraction procedure for the speciation of particulate trace metals. Anal. Chem., 51 (7), 844 - 851 
Table 1: The dumpsites locations and years of existence

\begin{tabular}{|l|l|l|}
\hline $\begin{array}{l}\text { Sampling } \\
\text { sites }\end{array}$ & Dumpsites Descriptions & $\begin{array}{l}\text { Years of } \\
\text { Existence }\end{array}$ \\
\hline A & $\begin{array}{l}\text { Airport Dumpsite, Near NASFAT Praying Ground Along } \\
\text { Lagos-Ogbomoso Road }\end{array}$ & 1998 \\
\hline B & Atoto Warehouse Dumpsite, New Yidi Road & 1985 \\
\hline C & $\begin{array}{l}\text { Asa-Dam Dumpsite, Near Kwara State House of Assembly } \\
\text { Complex }\end{array}$ & 1985 \\
\hline D & NISPRI Dumpsite, Asa-Dam Road & 1990 \\
\hline E & Gerewu Dumpsite, Hajj Camp Road & 2004 \\
\hline F & Ita-Amoh Dumpsite Along Ajase-Ipo Road & 1985 \\
\hline G & Oko-Olowo Dumpsite Along Alapa Road & 1999 \\
\hline H & Sango Shooting Range Dumpsite & 1985 \\
\hline
\end{tabular}

Table 2: pH, \% organic matter and \% moisture content of soil from 8 dumpsites

\begin{tabular}{|l|l|l|l|l|}
\hline S/N & Dumpsites & $\begin{array}{l}\text { Ph in 1:1 } \\
\text { soil-water } \\
\text { suspension }\end{array}$ & $\begin{array}{l}\text { \% Organic } \\
\text { matter }\end{array}$ & $\begin{array}{l}\text { \% } \\
\text { Moisture }\end{array}$ \\
\hline 1 & Sango Shooting Range & 7.4 & 4.13 & 1.00 \\
\hline 2 & NSITF, Asa-Dam & 6.1 & 2.35 & 0.40 \\
\hline 3 & Atoto Warehouse & 5.4 & 2.84 & 0.10 \\
\hline 4 & Gerewu, Hajj Camp Road & 7.1 & 1.64 & 0.40 \\
\hline 5 & Asa-Dam KWHA & 6.8 & 2.77 & 1.00 \\
\hline 6 & Ita-Amoh & 7.7 & 4.20 & 0.10 \\
\hline 7 & Oko-Olowo & 7.6 & 4.10 & 0.40 \\
\hline 8 & Airport Near NASFAT & 6.9 & 1.64 & 0.10 \\
\hline
\end{tabular}

Table 3: Comparative extractions of $\mathrm{Fe}, \mathrm{Mn}, \mathrm{Zn}, \mathrm{Cd}$, $\mathrm{Ph}$ with Dilute and concentrated $\mathrm{HNO}_{3}$ on dumpsitesoil samples.

\begin{tabular}{|c|c|c|c|c|c|c|c|c|c|c|}
\hline Dumpsite & $\begin{array}{l}\text { Amour } \\
\text { Mn g/k }\end{array}$ & $\begin{array}{l}\text { at of } \\
\text { g-soil }\end{array}$ & $\begin{array}{l}\text { Amou } \\
\mathrm{g} / \mathrm{kg}-\mathrm{s}\end{array}$ & of & $\begin{array}{l}\text { Amou } \\
\mathrm{g} / \mathrm{kg}-\mathrm{S}\end{array}$ & of & $\begin{array}{l}\text { Amou } \\
\text { soil }\end{array}$ & $\mathrm{Cd}$ & $\begin{array}{l}\text { Amour } \\
\mathrm{g} / \mathrm{kg}-\mathrm{sC}\end{array}$ & of \\
\hline & Dilute & Conc & Dilute & Conc & Dilute & Conc & Dilute & Conc & Dilute & Conc \\
\hline 1 & 17.3 & 24.45 & 13.32 & 202.2 & 16.81 & 17.82 & 0.02 & 0.02 & 3.2 & 7.65 \\
\hline 2 & 18 & 19.4 & 3.48 & 90.4 & 22.55 & 25.01 & 0.01 & 0.01 & 2.5 & 7.5 \\
\hline 3 & 9.1 & 18.3 & 61.27 & 120 & 12.05 & 16.68 & 0.01 & 0.01 & 1.06 & 6.11 \\
\hline 4 & 4.1 & 14 & 40.41 & 159.54 & 18.5 & 28.51 & 0.05 & 0.06 & 2.91 & 5.31 \\
\hline 5 & 9.7 & 12.2 & 45.3 & 134.25 & 0.51 & 0.64 & 0.01 & 0.01 & 1.76 & 4.52 \\
\hline 6 & 6.1 & 46.3 & 32.84 & 112.25 & 2.63 & 21.51 & 0.01 & 0.01 & 2.43 & 3.9 \\
\hline 7 & 5.5 & 13.8 & 4.52 & 103.4 & 0.26 & 14.76 & 0.02 & 0.02 & 2.51 & 3.92 \\
\hline 8 & 6.5 & 17.41 & 24.33 & 22.4 & 0.11 & 0.82 & 0.01 & 0.04 & 0.98 & 2.15 \\
\hline
\end{tabular}

Table 4: Normalisation of trace metals in dumpsites

\begin{tabular}{|l|l|l|l|l|l|}
\hline Dumpsite & $\mathrm{Mn}$ & $\mathrm{Fe}$ & $\mathrm{Zn}$ & $\mathrm{Cd}$ & $\mathrm{Pb}$ \\
\hline 1 & 1 & 8.25 & 0.688 & 0.001 & 0.338 \\
\hline 2 & 1 & 4.660 & 1.286 & 0.001 & 0.027 \\
\hline 3 & 1 & 6.557 & 0.984 & 0.001 & 0.018 \\
\hline 4 & 1 & 11.386 & 2.036 & 0.001 & 0.379 \\
\hline 5 & 1 & 11.004 & 0.052 & 0.004 & 0.062 \\
\hline 6 & 1 & 6.887 & 1.320 & 0.001 & 0.149 \\
\hline 7 & 1 & 7.493 & 1.070 & 0.001 & 0.284 \\
\hline 8 & 1 & 1.287 & 0.006 & 0.001 & 0.011 \\
\hline
\end{tabular}


Table 5: Mean concentrations (Metal in mg/kg-soil) of trace metals in step-wise extraction from the eight dumpsites in Ilorin

\begin{tabular}{|l|l|l|l|l|l|l|l|l|l|}
\hline Metal & Step & $\begin{array}{l}\text { Location } \\
\mathbf{1}\end{array}$ & $\begin{array}{l}\text { Location } \\
\mathbf{2}\end{array}$ & $\begin{array}{l}\text { Location } \\
\mathbf{3}\end{array}$ & $\begin{array}{l}\text { Location } \\
\mathbf{4}\end{array}$ & $\begin{array}{l}\text { Location } \\
\mathbf{5}\end{array}$ & $\begin{array}{l}\text { Location } \\
\mathbf{6}\end{array}$ & $\begin{array}{l}\text { Location } \\
\mathbf{7}\end{array}$ & $\begin{array}{l}\text { Location } \\
\mathbf{8}\end{array}$ \\
\hline $\mathrm{Mn}$ & 1 & 0.365 & 0.438 & 0.978 & 0.180 & 0658 & 0.296 & 0.510 & 0.646 \\
\hline $\mathrm{Mn}$ & 2 & 4.250 & 1.600 & 0.808 & 3.62 & 2.290 & 3.820 & 3.910 & 1.270 \\
\hline $\mathrm{Mn}$ & 3 & 6.670 & 3.960 & 1.74 & 4.49 & 7.78 & 2.06 & 6.41 & 5.17 \\
\hline $\mathrm{Mn}$ & 4 & 3.016 & 1.210 & 8.18 & 1.70 & 1.91 & 2.36 & 1.86 & 1.27 \\
\hline $\mathrm{Mn}$ & 5 & 0.099 & 0.034 & n.d. & 0.010 & 0.180 & 0.048 & 0.024 & n.d. \\
\hline $\mathrm{Fe}$ & 1 & 0.329 & 3.200 & 3.26 & 2.95 & 2.92 & 3.02 & 2.86 & 2.92 \\
\hline $\mathrm{Fe}$ & 2 & 0.830 & 0.892 & 1.17 & 1.17 & 0.924 & 0.011 & 0.83 & 0.610 \\
\hline $\mathrm{Fe}$ & 3 & 5.080 & 3.17 & 4.86 & 9.51 & 6.65 & 10.15 & 6.77 & 18.77 \\
\hline $\mathrm{Fe}$ & 4 & 242.3 & 244.6 & 72.40 & 247.7 & 446.8 & 327.7 & 236.9 & 86.90 \\
\hline $\mathrm{Fe}$ & 5 & 17.20 & 9.78 & 0.066 & 10.40 & 28.50 & 12.40 & 8.56 & 22.20 \\
\hline $\mathrm{Zn}$ & 1 & 0.132 & 0.075 & 0.105 & 0.145 & 0.089 & 0.088 & 0.127 & 0.075 \\
\hline $\mathrm{Zn}$ & 2 & 8.98 & 0.166 & 0.280 & 2.48 & 0.490 & 4.20 & 4.02 & 0.140 \\
\hline $\mathrm{Zn}$ & 3 & 5.66 & 0.118 & 0.108 & 1.42 & 1.55 & 0.172 & 1.03 & 0.086 \\
\hline $\mathrm{Zn}$ & 4 & 2.32 & 0.354 & 0.352 & 0.272 & 1.12 & 1.31 & 1.14 & 0.141 \\
\hline $\mathrm{Zn}$ & 5 & 0.110 & 0.060 & n.d. & n.d. & 0.066 & 0.006 & 1.80 & n.d. \\
\hline $\mathrm{Cd}$ & 1 & 0.028 & 0.027 & 0.024 & 0.025 & 0.025 & 0.026 & 0.022 & 0.023 \\
\hline $\mathrm{Cd}$ & 2 & 0.037 & 0.026 & 0.026 & 0.039 & 0.045 & 0.040 & 0.030 & 0.024 \\
\hline $\mathrm{Cd}$ & 3 & 0.013 & 0.074 & 0.069 & 0.091 & 0.013 & 0.013 & 0.048 & 0.005 \\
\hline $\mathrm{Cd}$ & 4 & 0.027 & 0.020 & 0.079 & 0.029 & 0.026 & 0.026 & 0.030 & 0.027 \\
\hline $\mathrm{Cd}$ & 5 & n.d. & n.d & n.d. & n.d. & n.d. & n.d. & n.d. & n.d. \\
\hline $\mathrm{Pb}$ & 1 & 0.970 & 0.96 & 0.936 & 0.928 & 0.918 & 0.932 & 1.054 & 0.880 \\
\hline $\mathrm{Pb}$ & 2 & 0.694 & 0.478 & 0.484 & 0.722 & 0.506 & 1.124 & 1.124 & 0.398 \\
\hline $\mathrm{Pb}$ & 3 & 0.338 & 0.314 & 0.230 & 0.488 & 0.158 & 0.346 & 0.740 & 0.168 \\
\hline $\mathrm{Pb}$ & 4 & 1.34 & 0.384 & 0.446 & 1.162 & 0.332 & 2.360 & 1.270 & 0.262 \\
\hline $\mathrm{Pb}$ & 5 & n.d. & n.d. & n.d. & n.d. & n.d. & n.d. & n.d. & n.d. \\
\hline $\mathrm{Key}$ & $\mathbf{n}$ & $\mathrm{d}$ & & & & & & \\
\hline
\end{tabular}

Key: n.d. = not detected

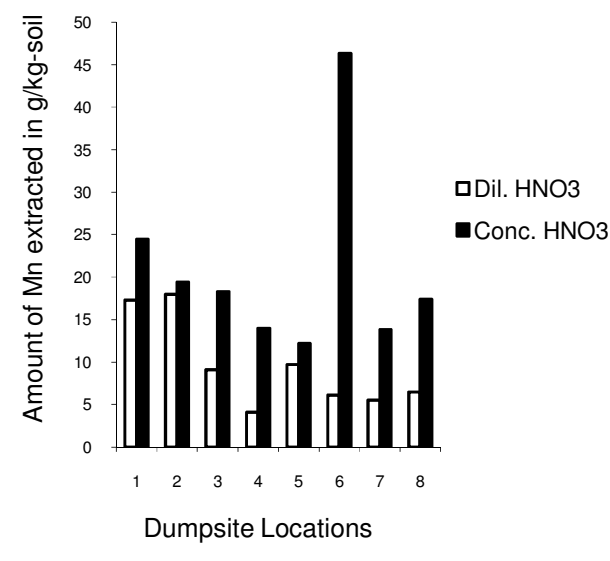

Fig. 2A: Comparative extraction of $\mathrm{Mn}$ by dil. and conc. $\mathrm{HNO}_{3}$

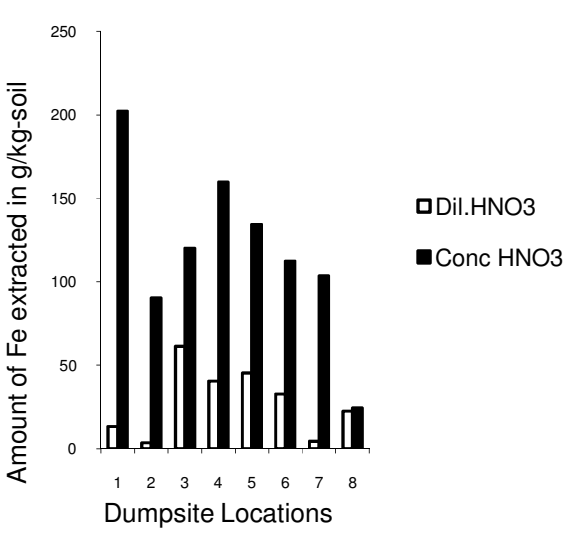

Fig. 2B: Comparative extraction of Fe by dil. and conc. $\mathrm{HNO}_{3}$ 


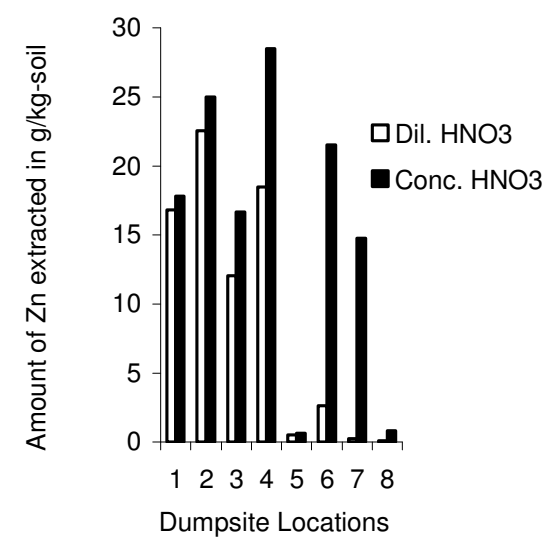

Fig. 2C: Comparative extraction of $\mathrm{Zn}$ by dil. and conc. $\mathrm{HNO}_{3}$

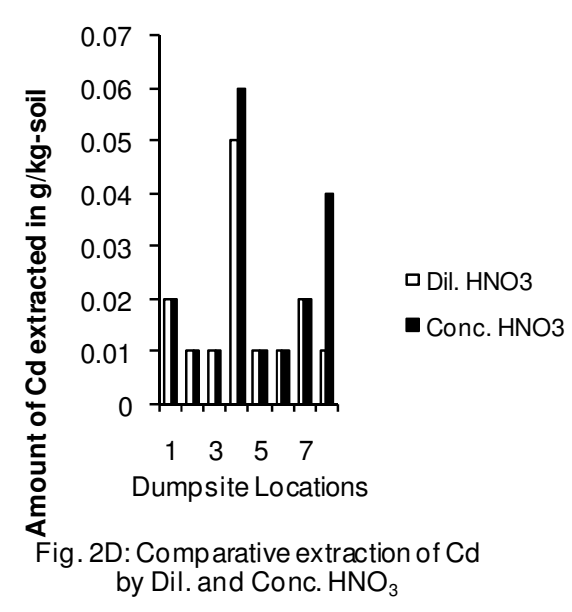

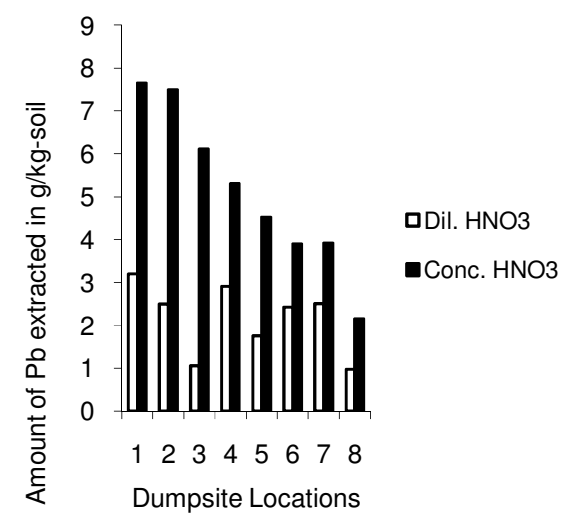

Fig. 2E: Comparative extraction of $\mathrm{Pb}$ by dil. and conc. HNO3 